\title{
ANALISA PENGARUH PERUBAHAN PENUTUPAN LAHAN TERHADAP DEBIT SUNGAI SUB DAS METRO DENGAN MENGGUNAKAN PROGRAM ARCSWAT
}

\author{
Ayisya Cindy Harifa ${ }^{1}$, Moh. Sholichin ${ }^{2}$, Tri Budi Prayogo ${ }^{2}$ \\ ${ }^{1}$ Mahasiswa Program Magister Teknik Pengairan, Fakultas Teknik, Universitas Brawijaya, Malang, Jawa Timur. \\ ${ }^{2}$ Dosen, Program Studi Magister Sumber Daya Air, Teknik Pengairan Fakultas Teknik, Universitas Brawijaya, \\ Malang, Jawa Timur, Indonesia \\ Email: Ayisya.ch989@gmail.com
}

\begin{abstract}
ABSTRAK: DAS memiliki karakteristik yang spesifik sebagai daerah hidrologi, berkaitan dengan unsur utamanya seperti jenis tanah, tata guna lahan, topografi, kemiringan dan panjang lereng. Analisa karakteristik tersebut dilakukan dengan menggunakan pemodelan Soil Water Assesment Tool (SWAT). Tujuan penelitian ini adalah, mengidentifikasi kondisi eksisting tahun 2014, mengetahui pola perubahan lahan tahun 2002, 2006, 2009, dan 2014, mengetahui dampak perubahan terhadap Curve Number, limpasan permukaan dan sedimen, menilai kondisi DAS. Hasil simulasi menunjukkan bahwa perubahan penutupan lahan menyebabkan nilai CN, limpasan dan debit sungai semakin besar. Nilai $\mathrm{CN}$ berada di kisaran $11-96$, debit rata-rata tahunan berkisar antara $1.923-3.591 \mathrm{~m}^{3} / \mathrm{dt}$, dan besarnya limpasan yang terjadi sebesar $3.03-1914.28 \mathrm{~mm}$. Berdasarkan hasil kalibrasi, hasil menunjukkan p-faktor sebesar 0.85, dan p-faktor hasil validasi sebesar 0.83, sehingga simulasi dianggap valid. Penilaian kinerja DAS menunjukkan bahwa di wilayah studi dalam kategori kinerja yang buruk.
\end{abstract}

Keyword: Penutupan Lahan, Limpasan, ARCSWAT

\begin{abstract}
Watershed as hydrologic area, characterized by specific element such as soil, land cover, topographic, land slope and length of slope. Soil Water Assessment Test (SWAT) is a suitable hydrologic modeling system to analyze many character in watershed. The aim of this study are to identified land cover in 2014, to determine the pattern of land cover changes in 2002, 2006, 2009 and 2014, determine the impact of land cover changes related to curve number, surface runoff, and sedimentation, assess the watershed condition. Simulation result showed that land cover changes have resulted in corresponding increase in curve number, surface runoff, and stream flow. Curve number was about $11-96$, yearly discharge was about $1.923-3.591 \mathrm{~m}^{3} / \mathrm{s}$, and surface runoff was about $3.03-1914.28 \mathrm{~mm}$. Calibration result showed that p-factor value is 0.85 , and validation result showed that p-factor value of 0.83 , it means that simulation was valid. Base on watershed assessment, concordance of land cover and surface runoff in the bad category.
\end{abstract}

Keyword: Land Cover, Surface Runoff, ARCSWAT

Daerah aliran sungai merupakan sistem biofisik yang di dalamnya terdapat siklus hidrologi yang berlangsung secara terus menerus. Beberapa proses tersebut seperti evaporasi, transpirasi, evapotranspirasi, kondensasi, presipitasi, infiltrasi, perkolasi, dan limpasan. Proses tersebut akan mendukung satu dengan yang lain, sehingga akan membuat sistem yang kompleks dalam suatu DAS (Sosrodarsono \& Takeda, 1997).
Berkaitan dengan limpasan permukaan, jenis penutupan lahan akan menjadi tolak ukur seberapa besar limpasan permukaan yang akan terjadi, seperti kawasan hutan akan memiliki limpasan permukaan yang kecil karena kapasitas infiltrasi yang besar. Apabila kawasan hutan ini diubah menjadi lahan terbuka atau permukiman, maka akan menyebabkan berkurangnya kapasitas infiltrasi karena pemampatan permukaan tanah. Air 
akan lebih mudah mengalir menuju sungai, sehingga volume air sungai akan lebih cepat naik dan akan menyebabkan banjir.

Analisa yang paling mudah untuk menggambarkan kondisi DAS yang kompleks adalah dengan memodelkannya. Model hidrologi DAS menggambarkan interaksi antar variabel-variabel di dalam konteks DAS. Perkembangan model hidrologi DAS seiring dengan perkembangan teknologi Sistem Informasi Geografis (SIG) dan penginderaan jauh. Penggunaan model hidrologi DAS yang sering digunakan adalah pemodelan tata ruang berdasarkan data penggunaan/penutupan lahan, peramalan dan prediksi kondisi suatu perubahan/perlakuan untuk kondisi banjir, kekeringan, erosi, sedimentasi dan kondisi lain (PPSL-Unmul, 1997).

Tujuan penelitian ini adalah, mengidentifikasi kondisi eksisting tahun 2014, mengetahui pola perubahan lahan mulai tahun 2002, 2006, 2009, dan 2014, mengetahui dampak perubahan terhadap Curve Number, limpasan permukaan dan sedimen, menilai kondisi DAS. Serta melakukan penilaian pada kinerja DAS pada tahun 2014, menggunakan Peraturan Kememterian Kehutanan Nomor: 52/Kpts-II/2001.

\section{Klasifikasi Citra}

Tahap ini merupakan proses pembagian daerah cakupan berdasarkan jenis objek dengan cara menginterpretasi kenampakan berdasarkan data citra dengan menggunakan simbol tertentu. Metode yang digunakan terdapat dua jenis yaitu metode klasifikasi tidak terawasi (unsupervised) dan klasifikasi terawasi (supervised). Klasifikasi tidak terawasi mengelompokkan data dengan analisis kluster secara otomatis dengan menghitung kembali rata-rata kelas secara berulang. Klasifikasi terawasi mengelompokkan data dengan training area untuk tiap kategori penutup lahan yang mewakili.

\section{Klasifikasi Tidak Terawasi (Unsupervised)}

Klasifikasi tidak terbimbing merupakan metode yang memberikan mandat sepenuhnya kepada sistem/komputer untuk mengelompokkan data raster berdasarkan nilai digitalnya masing-masing, intervensi pengguna dalam hal ini diminimalisasi. Jenis metode ini digunakan bila kualitas citra sangat tinggi dengan distorsi atmosferik dan tutupan awan yang rendah. Namun, dalam banyak kasus, terlepas dari kondisi citra yang bersangkutan, metode ini banyak digunakan untuk memberikan gambaran kasar/ informasi awal.

\section{Klasifikasi Terawasi (Supervised)}

Klasifikasi terbimbing merupakan metode yang dipandu dan dikendalikan sebagian besar atau sepenuhnya oleh pengguna dalam proses pengklasifikasiannya. Intervensi pengguna dimulai sejak penentuan training area hingga tahap pengklasterannya. Klasifikasi terbimbing dalam hal ini mensyaratkan kemampuan pengguna dalam penguasaan informasi lahan terhadap areal kajian.

\section{Perhitungan Akurasi (Accuracy Assessment)}

Seperti halnya dengan beberapa analisa spasial lainnya, sebelum hasil klasifikasi dapat benar-benar digunakan perhitungan tingkat akurasi merupakan prasyarat mutlak yang harus dilakukan setelah kegiatan klasifikasi.

Menurut Riswanto (2009), perhitungan nilai akurasi bertujuan untuk mengetahui tingkat ketepatan dalam sebuah proses klasifikasi. Perhitungan akurasi dapat dilakukan dengan berbagai metode, salah satu metodenya adalah Confusion Matrix. Pada prinsipnya, Confusion Matrix menyusun data hasil klasifikasi dan hasil pengamatan di lapangan dalam sebuah tabel perbandingan persentase.

Parameter yang digunakan dalam perhitungan akurasi dengan metode confusion matrix adalah: akurasi pembuat (Prodecers Accuracy), akuasi pengguna (users accuracy), akurasi keseluruhan (Overall Accuracy), dan koefisien Kappa.

Producers accuracy adalah akurasi yang dihasilkan oleh pembuat klasifikasi dengan cara pembagian pixel yang benar dengan jumlah total pixel dalam satu kolom. Users accuracy adalah akurasi yang dihasilkan pengguna yang diperoleh dari pembagian antara jumlah pixel yang benar dengan total pixel dalam baris yang sama. Overall accuracy dihasilkan dari perbandingan jumlah pixel yang benar dengan total pixel keseluruhan. Nilai akurasi yang banyak digunakan adalah akurasi kappa karena akurasi ini memperhitungkan semua pixel yang digunakan. Nilai kappa ini digunakan untuk menguji kesignifikanan antara dua band yang berbeda. Pembuatan matrik kesalahan dan penentuan nilai akurasi adalah sebagai berikut: 
Tabel 1. Bentuk Matrik Kesalahan

\begin{tabular}{|c|c|c|c|c|c|c|}
\hline \multirow[t]{2}{*}{ Kelas Referensi } & \multicolumn{3}{|c|}{ Data klasifikasi peta } & \multirow{2}{*}{$\begin{array}{l}\text { Total } \\
\text { Pixel } \\
\text { Baris }\end{array}$} & \multirow{2}{*}{$\begin{array}{c}\text { User's } \\
\text { Accuracy } \\
(\%)\end{array}$} & \multirow{2}{*}{$\begin{array}{c}\text { Producer's } \\
\text { Accuracy } \\
\text { (\%) }\end{array}$} \\
\hline & A & B & $\mathrm{C}$ & & & \\
\hline A & $X_{11}$ & $\mathrm{X}_{12}$ & $X_{13}$ & $\mathrm{X}_{1+}$ & $\mathrm{X}_{11} / \mathrm{X}_{1+}$ & $\mathrm{X}_{11} / \mathrm{X}_{+1}$ \\
\hline B & $X_{21}$ & $\mathrm{X}_{22}$ & $\mathrm{X}_{23}$ & $\mathrm{X}_{2+}$ & $\mathrm{X}_{22} / \mathrm{X}_{2+}$ & $\mathrm{X}_{22} / \mathrm{X}_{+2}$ \\
\hline $\mathrm{C}$ & $X_{31}$ & $\mathrm{X}_{32}$ & $\mathrm{X}_{33}$ & $\mathrm{X}_{3+}$ & $\mathrm{X}_{33} / \mathrm{X}_{3+}$ & $\mathrm{X}_{33} / \mathrm{X}_{+3}$ \\
\hline Total Pixel Kolom & $X_{+1}$ & $\mathrm{X}_{+2}$ & $X_{+3}$ & $\mathrm{~N}$ & & \\
\hline
\end{tabular}

Sumber: Eris Riswanto,2009

Kappa Accuracy $=$
$\left[\left(N \sum_{I=1}^{R} X_{I I}\right)-\left(N^{2}-\sum_{I=1}^{R} X_{1+} X_{+1}\right)\right] \times 100 \%$

Overall Accuracy =

$\left[\frac{\left(\Sigma_{i=1}^{r} X_{\text {ii }}\right)}{N}\right] \times 100 \%$

\section{Limpasan Permukaan}

Limpasan permukaan (runoff) adalah bagian dari air hujan, terjadi ketika curah hujan melampaui laju infiltrasi. Setelah laju infiltrasi terpenuhi, air mulai mengisi cekungancekungan atau depresi pada permukaan tanah. Setelah pengisian selesai maka air akan mengalir dengan bebas di permukaan tanah (Sari, 2011). Air hujan yang menjadi limpasan permukaan sangat bergantung pada intensitas hujan, penutupan lahan, dan kejadian hujan sebelumnya (berhubungan dengan kadar air tanah sebelum terjadi hujan). Kadar air tanah sebelum terjadinya hujan biasanya disebut Antecedent Moisture Content (AMC) (Rahim, 2006).

Jumlah dan kecepatan aliran permukaan selain bergantung kepada luas areal tangkapan, juga yang tidak kalah pentingnya kepada koefisien runoff dan intensitas hujan maksimum. Aliran permukaan dengan jumlah dan kecepatan yang besar sering menyebabkan pemindahan atau pengangkutan massa tanah secara besar-besaran. Inilah yang sering diistilahkan dengan banjir. Banjir ini meluapkan sedimentasi depresi alami, saluransaluran, anak-anak sungai, sungai-sungai, dan selanjutnya waduk-waduk (Rahim, 2006)

\section{Soil Water Assessment Tool (SWAT)}

SWAT atau Soil and Water Assessment Tool merupakan model hidrologi berbasis fisik untuk kejadian kontinu (continuous-event) yang dikembangkan untuk memprediksi dampak praktek pengelolaan lahan terhadap air, sedimen, dan kimia pertanian dalam skala yang besar, yaitu Daerah Aliran Sungai (DAS) yang kompleks dengan jenis tanah, penutupan lahan, dan kondisi pengelolaan yang bervariasi untuk jangka waktu yang lama (Neitsch, Arnold, Kiniry, Srinivasan, \& William, 2004).

SWAT model dikembangkan oleh Dr. Jeff Arnold pada awal tahun 1990-an untuk pengembangan Agricultural Research Service (ARS) dari USDA. Model tersebut dikembangkan untuk melakukan prediksi dampak dari manajemen lahan pertanian terhadap air, sedimentasi, dan jumlah bahan kimia, pada suatu area DAS yang kompleks dengan mempertimbangkan variasi jenis tanahnya, tata guna lahan, serta kondisi manajemen suatu DAS setelah melalui periode yang lama. SWAT merupakan hasil gabungan dari beberapa model, di antarnya adalah Simulator for Water Resources in Rural Basin (SWWRRB), Chemical, Runoff and Erosion from Agricultural Management System (CREAMS), Groundwater Loading Effect an Agricultural Management System (GREAMS), dan Erosion Productivity Impact Calculator (EPIC) (Neitsch, Arnold, Kiniry, Srinivasan, \& William, 2004)

Apapun kajian yang dilakukan dengan menggunakan SWAT, neraca air tetap dihasilkan dari setiap hal yang terjadi dalam DAS. Untuk prediksi secara akurat terhadap pergerakan pestisida, sedimen atau unsur hara, siklus hidrologi yang disimulasikan oleh model harus dikonfirmasikan dengan proses yang terjadi di dalam DAS. Simulasi hidrologi DAS dapat dipisahkan menjadi dua bagian utama. Bagian pertama adalah fase lahan dari siklus hidrologi Fase lahan siklus hidrologi mengontrol jumlah air, sedimen, unsur hara dan pestisida yang bergerak menuju saluran utama pada masing-masing Sub DAS. Bagian kedua adalah fase air atau penelusuran dari siklus hidrologi yang dapat didefinisikan sebagai pergerakan air, sedimen dan lainnya melalui jaringan sungai dalam DAS menuju ke outlet.

Siklus hidrologi yang digambarkan didasarkan pada persamaan keimbangan air di DAS yaitu:

$S W_{\mathrm{t}}=S W_{0}+\sum_{t=i}^{t}\left(R_{d a y}-Q_{z u r f}-E_{a}-W_{z x p p}-Q_{g w}\right)$

Keterangan:

$\mathrm{SW}_{\mathrm{t}}$ : kandungan akhir air tanah (mm)

$\mathrm{SW}_{0}$ : kandungan air tanah awal pada hari ke-i (mm)

$\mathrm{R}_{\text {day }} \quad$ : jumlah presipitasi hari ke-i (mm) 
$\mathrm{Q}_{\text {surf }}$ : jumlah limpasan permukaan pada hari ke-i (mm)

$\mathrm{E}_{\mathrm{a}} \quad$ : jumlah evapotranspirasi pada hari ke$\mathrm{i}(\mathrm{mm})$

$\mathrm{W}_{\text {seep }}$ : jumlah air yang memasuki vadose zone pada profil tanah hari ke-i (mm)

$\mathrm{Q}_{\mathrm{gw}}$ : jumlah air yang kembali hari ke-I (mm)

Metode yang digunakan SWAT untuk mengestimasikan limpasan permukaan seperti persamaan di atas dan infiltrasi Green and Ampt. SCS-CN merupakan fungsi dari permeabilitas tanah, tata guna lahan dan kondisi air tanah.

Besarnya laju $\mathrm{W}_{\text {seep }}$ dan $\mathrm{Gw}$ ditung dengan persamaan (Neitsch, Arnold, Kiniry, Srinivasan, \& William, 2004):

$\mathrm{W}_{\text {seep }}=\mathrm{W}_{\text {percy,ly=n }}+\mathrm{W}_{\text {crk,btm }}$

Keterangan:

Wseep = Total air yang berada di bawah tanah pada hari ke-i (mm)

$\mathrm{W}_{\text {percy,ly=n }} \quad$ = Jumlah air perkolasi yang keluar dari lapisan terbawah (mm)

$\mathrm{W}_{\text {crk,btm }} \quad=$ Jumlah air yang mengalir melewati lapisan yang lebih bawah dari muka tanah untuk mengalirkan aliran pada hari ke-i (mm)

$\mathrm{Q}_{\mathrm{gw}} \quad=800 \mu . \alpha_{\mathrm{gw}} \cdot \mathrm{h}_{\mathrm{wtbl}}$

Keterangan:

$\mathrm{Q}_{\mathrm{gw}} \quad$ : Jumlah air yang kembali pada hari ke-i (mm)

$\mu \quad$ : Specific yield dari akuifer dangkal $(\mathrm{m} / \mathrm{m})$

$\alpha_{\mathrm{gw}} \quad$ : Konstanta resesi aliran mantap

$\mathrm{h}_{\mathrm{wtbl}} \quad$ : Tinggi muka air pada watertable $(\mathrm{m})$

Pada penentuan nilai evapotranspirasi,

model SWAT melakukan perhitungan berdasarkan tiga metode, yaitu metode Penman-Monteith, metode Priestley and Taylor, serta metode Hargreaves. Metode Penman-Monteith merupakan salah satu metode perhitungan besar evapotranspirasi potensial dari permukaan air terbuka maupun permukaan vegetasi. Model ini membutuhkan lima parameter iklim, yaitu suhu, kelembaban relatif, kecepatan angin, tekanan uap jenuh, dan radiasi netto. Persamaan Penman-Monteith disajikan berikut ini: $\lambda E=\frac{\Delta\left(H_{\text {net }}-G\right)+\rho_{\text {air }} C_{p}\left[e_{z}^{0} e_{z}\right] / r a}{\Delta+\gamma(1+r c / r a)}$

Keterangan:

$E \quad$ : laju evaporasi $(\mathrm{m} / \mathrm{s})$

$\lambda \mathrm{E}$ : panas laten akibat densitas sinar matahari $\left(\mathrm{MJ} / \mathrm{m}^{2} /\right.$ day $)$

$\Delta \quad$ : kemiringan pada kurva tekanan uap air jenuh - temperatur, de/dT $(\mathrm{kPao} / \mathrm{C})$

$H_{\text {net }}$ : radiasi yang mengenai permukaan $\left(\mathrm{W} / \mathrm{m}^{2}\right)$

$G$ : kerapatan fluks panas ke tanah $\left(\mathrm{MJ} / \mathrm{m}^{2} /\right.$ day $)$

$c_{\mathrm{p}}$ : kapasitas panas spesifik dari udara $(\mathrm{J} / \mathrm{kg} / \mathrm{K})$

$\rho_{\text {air }} \quad$ densitas udara $\left(\mathrm{kg} / \mathrm{m}^{3}\right)$

$e_{z}^{0} \quad$ : tingkat tekanan uap air jenuh di udara pada ketinggian $\mathrm{z}(\mathrm{kPa})$

$e_{z} \quad$ : tekanan uap air di udara pada ketinggia $\mathrm{z}(\mathrm{kPa})$

$r_{\mathrm{c}} \quad$ : resistensi dari kanopi tanaman $(\mathrm{s} / \mathrm{m})$

$g_{\mathrm{s}}$ : difusi resistensi lapisan udara atau aerodynamic resistance $(\mathrm{s} / \mathrm{m})$

$\gamma \quad$ : konstanta Psychrometri $(\gamma \approx 66 \mathrm{~Pa} / \mathrm{K})$

\section{Kalibrasi dan Validasi ARCSWAT}

Perkembangan teknologi saat ini sangat membantu dalam setiap kegiatan yang dilakukan manusia, seperti halnya dalam melakukan kalibrasi dan validasi pemodelan suatu DAS. Terdapat software yang dapat membantu dalam melakukan kalibrasi dan validasi model yang menggunakan ARCSWAT, yaitu Soil Water Assessment Tool-Calibration and Uncertainty Program (SWAT-CUP). SWAT-CUP memiliki empat macam model kalibrasi yaitu SUFI-2, GLUE, ParaSol dan MCMC. Selain melakukan kalibrasi dan validasi, SWAT-CUP juga dapat melakukan analisa sensitivitas dan analisa ketidak pastian pada model hidrologi.

SUFI-2 sangat dianjurkan untuk digunakan, karena ketidakpastian masukan digambarkan memiliki distribusi yang seragam, sehingga memudahkan dalam menganalisa parameter-parameter yang ada dalam model ARCSWAT. Ketidakpastian output dikalibrasi menggunakan metode $95 \%$ Prediction Uncertainty (95PPU). 95PPU ditung pada level $2.5 \%$ hingga $97.5 \%$ dari distribusi komulatif variabel output dengan menggunakan Latin Hypercube Sampling. 95PPU menggambarkan luasan ketidakpastian, apabila data observasi bersinggungan dengan luasan 95PPU, maka parameter masukan yang 
sesuai dengan karakteristik DAS dapat ditinjau. Konsep tersebut dijelaskan melalui grafik berikut ini.

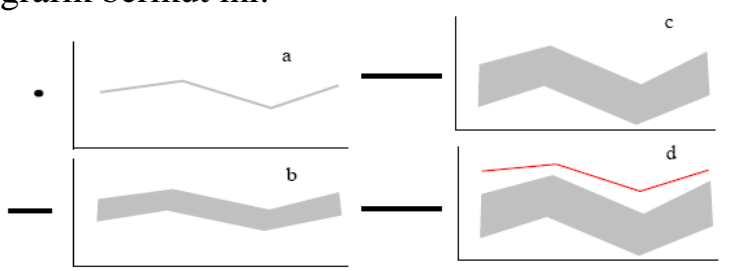

Gambar 1. Ilustrasi Grafik 95PPU Sumber: Rau, (2012:9)

Ilustrasi tersebut menggambarkan bahwa apabila terdapat satu parameter masukan yang berupa titik (gambar a) akan memberikan pengaruh tunggal yang digambarkan dengan garis abu-abu, kemudian terdapat penambahan parameter masukan yang akan berdampak pada peningkatan ketidakpastian (gambar b) digambarkan dengan titik yang berubah menjadi garis hitam dan menebalnya garis warna abu-abu menjadi area yang memiliki luasan, kemudian apabila parameter semakin bertambah panjang lagi maka area tersebut akan semakin menebal (gambar c) hal tersebut menggambarkan bahwa semakin bertambahnya parameter maka akan menambah ketidakpastian pada model. Area abu-abu tersebut merupakan ilustrasi luasan 95PPU. Terdapat beberapa kondisi yang harus dipahami pada proses kalibrasi yaitu:

1. Apabila data observasi yang digambarkan dengan garis merah berpotongan dengan area 95PPU di sepanjang area tersebut maka masukan kalibrasi dapat dikatakan valid.

2. Apabila tidak terjadi perpotongan disepanjang luasan, range parameter masukan harus diubah.

3. Apabila range parameter sudah sesuai dengan nilai fisik akan tetapi tetap tidak berpotongan maka permasalahan yang terjadi bukan pada parameter, akan tetapi berasal dari konsep model.

Dalam proses kalibrasi tersebut indikator yang dilihat berupa grafik, sehingga diperlukan parameter pengukuran kualitas kalibrasi dan validasi. SWAT-CUP menampilkan parameter yang digunakan dalam menilai kualitas kalibrasi dan validasi yaitu (Rau, 2012):

1. p-faktor (percentage factor) merupakan nilai yang menggambarkan perpotongan antara hasil observasi dan 99PPU, apabila nilai tersebut mendekati 1 atau $p$ faktor $>0.8$ maka model dianggap valid.
2. $\mathrm{r}$-faktor (relatives width factor) menggambarkan kualitas kalibrasi yang mengindikasikan ketebalan 95PPU. Nilai ini dihitung berdasarkan jarak rerata antara nilai maksimum dan minimum 95PPU, yang dibagi dengan standar deviasi data observasi, sehingga apabila nilai $r$-faktor mendekati 0 maka model dianggap semakin baik.

3. NS (Nash-Sutcliffe) adalah sebaran normal yang mengindikasikan jarak perbedaan antara hasil simulasi dan observasi. NS mengindikasikan seberapa dekat hasil simulasi dengan data observasi. Nilai NS adalah antara 0 hingga 1, nilai NS mendekati 1 merupakan indikator bahwa hasil simulasi sangat mendekati keadaan di lapangan.

4. $\mathrm{R}^{2}$ merupakan indeks validitas yang mengukur kebaikan suai atau goodness of fit suatu persamaan regresi, sehingga persentase variasi total data dalam variabel terikat yang dijelaskan oleh variabel bebas diharuskan memiliki karakteristik atau fluktuasi sebaran yang sama.

\section{METODOLOGI PENELITIAN}

\section{a. Lokasi Penelitian}

Penelitian ini dilaksanakan di Sub-DAS Metro Hulu, yang secara geografis terletak antara $112^{\circ} 27^{\prime} 49.85^{\prime \prime}-112^{\circ} 36^{\prime} 56.56^{\prime \prime}$ BT dan $7^{\circ} 55^{\prime} 13.08^{\prime \prime}-7^{\circ} 58^{\prime} 36.14$ "LS, berada di zona 49 Selatan. Luas Sub-DAS Metro adalah \pm 271.06 $\mathrm{Km}^{2}$. Tidak seluruh area Sub-DAS Metro digunakan sebagai area penelitian, hanya sebagian wilayah yaitu sebesar $\pm 70.865 \mathrm{Km}^{2} \mathrm{di}$ daerah hulu Sub-DAS Metro.

b. Bahan dan Alat Penelitian ini yaitu:

Bahan yang digunakan dalam penelitian

1. Peta rupa bumi.

2. Peta jenis tanah Skala 1:250.000. Peta tanah terdapat pada gambar 2 .

3. Data hujan tahun 2002-2011 untuk 5 stasiun hujan (Stasiun Kedungrejo, Stasiun Temas, Stasiun Dau, Stasiun Blimbing, Stasiun Sukun). Lokasi stasiun hujan dapat dilihat pada gambar 3.

4. Data suhu, penyinaran matahari, kelembaban relatif, kecepatan angin tahun 2002-2011. 
5. Data debit observasi bulanan tahun 20022011 dengan koordinat outlet atau titik observasi debit adalah 759'33.91"LS dan $113^{\circ} 10^{\prime} 24.17 " B T$.

6. Citra Landsat 7 ETM tanggal 17 Juni 2001, 17 Juli 2006 dan 9 Juli 2009.

7. Citra Landsat 8 OLI/TIRS tanggal 1 September 2014.

Alat yang digunakan adalah perangkat computer dengan software ArcGIS 10.1, ENVI-5, SWAT-CUP, Google Earth, Microsoft Office, dan program ARCSWAT, serta software pendukung yang lain.

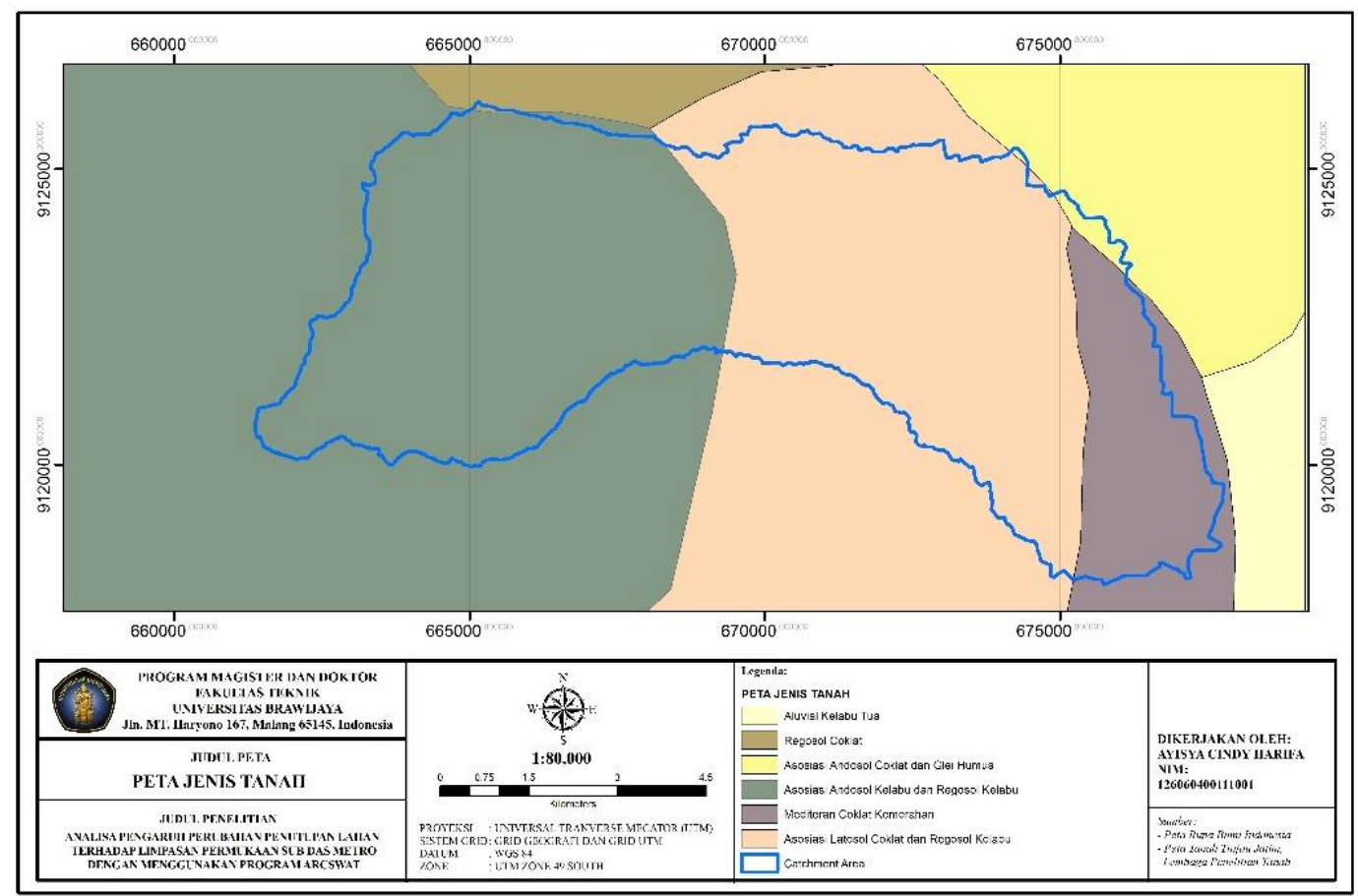

Gambar 2. Peta Jenis Tanah

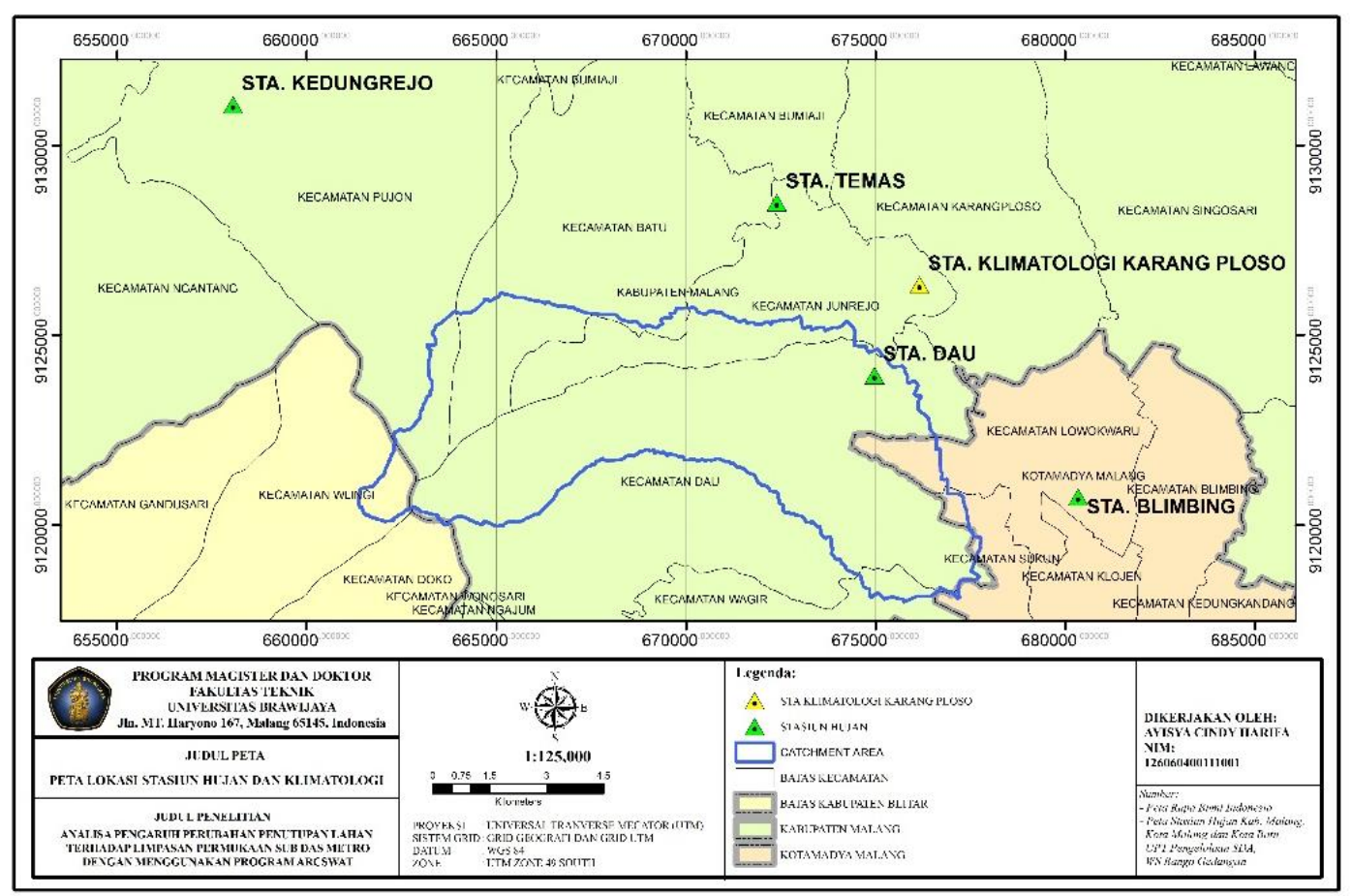

Gambar 3. Peta Lokasi Stasiun Hujan dan Klimatologi 


\section{c. Metode Penelitian}

Tahapan penelitian ini terdiri dari 7 tahapan, yaitu: 1) Pengumpulan data, 2) Pengolahan data, 3) Analisa 4) Kalibrasi, 6) Simulasi, dan 7) Penilaian kinerja DAS.

\section{Pengumpulan Data}

Pengumpulan data dilakukan dari beberapa instansi terkait seperti Badan Meteorologi dan Geospasial. Peta Tanah dari Lembaga Penelitian Tanah, dan Data Citra Satelit dari USGS.

\section{Pengolahan Data}

Data-data yang dapat diolah oleh ARCSWAT adalah data-data dengan format raster atau features. Sedangkan data citra yang diperoleh masih dalam bentuk band-band, sehingga data citra harus diproses terlebih dahulu, seperti composite band, pemotongan, dan klasifikasi.

Proses klasifikasi dilakukan dengan metode supervised dengan bantuan software ENVI.5.0. Apabila sudah terbentuk peta penutupan lahan maka dilakukan koreksi statistik.

Keakuratan hasil klasifikasi dapat dianalisa secara kuantitatif untuk mendukung evaluasi secara visual. Analisa klasifikasi dari data citra satelit dapat dikontrol dengan menggunakan suatu matrik kontingensi yaitu matrik bujur sangkar yang memuat jumlah pixel yang diklasifikasikan. Matrik tersebut sering disebut sebagai "Error Matrix" atau "confusión matrix". Nilai akurasi ditentukan oleh beberapa parameter seperti producer's accuracy, user's accuracy, overall accuracy dan nilai Kappa.

Nilai dari parameter tersebut didapatkan dari matriks konfusi berdasarkan overlay hasil klasifikasi dengan data citra asli. Nilai overall dan kappa accuracy diterima jika lebih dari $85 \%$.

\section{Analisa}

Analisa data pada penelitian ini ditujukan pada proses simulasi ARCSWAT, dengan proses sebagai berikut:

a. Deliniasi daerah observasi

Metode yang digunakan dalam proses deliniasi adalah metode threshold, dimana besar kecil nilai threshold yang digunakan akan menentukan jumlah jaringan sungai yang terbentuk. b. Pembentukan HRU (Hydrological
Response Unit)
HRU adalah unit satuan lahan dengan unsur karakteristik sub DAS yang berpengaruh terhadap terjadinya erosi. Setiap HRU akan memiliki informasi sub DAS, nomor HRU, jenis penutupan lahan, jenis tanah, dan luas HRU. HRU didapatkan dari peta tanah dan peta penggunaan lahan.

c. Penggabungan HRU Dengan Data Iklim Proses penggabungan HRU dan data iklim dilakukan setelah satuan analisis terbentuk. Pada tahap ini ditentukan periode simulasi terlebih dahulu untuk kemudian dilakukan pemasukan data iklim. Pembentukan Simulasi

d. Set Up dan Run

Proses Set Up yaitu pengaturan tanggal awal dan akhir simulasi, termasuk pengaturan jenis simulasi harian, bulanan atau tahunan, serta pengaturan jenis perangkat yang digunakan dan jenis output yang diiginkan.

e. Visualisasi

Setelah simulasi selesai dilakukan maka hasil simulasi akan di import dalam bentuk Microsoft access, untuk memudahkan pembacaan output. Setelah itu proses selanjutnya adalah menampilkan hasil simulasi yang kemudian dibandingkan dengan data hasil observasi.

Hasil simulasi yang dibandingkan dengan data observasi adalah debit yang berada pada file ARCSWAT output. Data yang digunakan adalah data yang ada pada sub basin terakhir.

\section{Kalibrasi dan Validasi}

Kalibrasi dan validasi memiliki tujuan agar hasil simulasi menyerupai keadaan sesungguhnya di lapangan. Kalibrasi menggunakan software SWAT-CUP dengan program SUFI-2. Kalibrasi dan validasi dilakukan dengan cara membandingkan hasil simulasi dengan debit bulanan hasil observasi.

Untuk kalibrasi menggunakan data observasi tahun 2002 hingga 2006 untuk validasi menggunakan data 2007 hingga 2011.

\section{Penilaian Kinerja DAS}

Penilaian ini digunakan untuk menentukan nilai atau status suatu lokasi berdasarkan beberapa kriteria di lokasi yang bersangkutan. Kriteria dan indikator kinerja DAS perlu ditentukan karena keberhasilan maupun kegagalan hasil kegiatan pengelolaan 
DAS dapat dimonitor dan di evaluasi melalui kriteria dan indikator yang telah ditetapkan. Kriteria dan indikator yang digunakan dalam hal ini berdasarkan Keputusan Kementerian Kehutanan Nomor: 52/Kpts-II/2001 tentang pedoman penyelenggaraan Pengelolaan Daerah Aliran Sungai.

\section{HASIL DAN PEMBAHASAN}

\section{a. Klasifikasi Penutupan Lahan}

Klasifikasi data citra dilakukan dengan menggunakan software ENVI 5.0 dengan metode klasifikasi terbimbing.

Klasifikasi menggunakan enam kategori yaitu hutan lahan kering primer, hutan tanaman industri, sawah, pemukiman, semak belukar dan tanah terbuka.

Berdasarkan hasil klasifikasi lahan tahun 2002, 2006, 2009 dan 2014, maka didapatkan tutupan lahan yang mendominasi di setiap tahunnya. Pada tahun 2002 fungsi yang mendominasi adalah hutan tanaman industri sebesar $29.24 \%$.

Pada tahun 2006 fungsi lahan yang mendominasi adalah sawah sebesar $32.99 \%$. Pada tahun 2009 fungsi lahan yang mendominasi adalah pemukiman sebesar $33.37 \%$. Seperti tahun 2009, fungsi lahan yang mendominasi penutupan lahan tahun 2014 adalah pemukiman, meningkat hingga $42.02 \%$.

Berdasarkan hasil klasifikasi yang ditampilkan pada tabel 2, maka overall accuracy terendah yang didapatkan adalah 89.912\% dengan kappa accuracy sebesar 0.879 sehingga dapat disimpulkan bahwa analisa data citra secara keseluruhan dapat diterima.
Tabel 2. Rekapitulasi Nilai Evaluasi Klasifikasi Penutupan Lahan

\begin{tabular}{|c|c|r|}
\hline & $\begin{array}{c}\text { Overall } \\
\text { Accuracy } \\
(\%)\end{array}$ & $\begin{array}{c}\text { Kappa } \\
\text { Accuracy }\end{array}$ \\
\hline 2002 & 89.912 & 0.879 \\
\hline 2006 & 93.412 & 0.921 \\
\hline 2009 & 91.257 & 0.895 \\
\hline 2014 & 90.794 & 0.890 \\
\hline
\end{tabular}

b. Analisa Perubahan Luas Penutupan Lahan Perubahan penutupan lahan erat kaitannya dengan jumlah penduduk, dengan bertambahnya waktu maka jumlah penduduk akan semakin meningkat yang diiringi dengan kebutuhan lahan yang semakin tinggi, sehingga akan mengurangi lahan yang memiliki tutupan vegetasi. Banyak penelitian yang telah membuktikan bahwa berkurangnya lahan bervegetasi akan berpengaruh pada kondisi banjir baik volume, frekuensi dan debit di suatu wilayah.

Berdasarkan tabel 3, luas penutupan lahan dari tahun 2002 hingga tahun 2014 perubahan yang paling terlihat adalah pada fungsi lahan Hutan Tanaman Industri dan Permukiman. Fungsi Hutan Tanaman Industri berkurang hingga $33.96 \%$, dan pemukiman bertambah hingga $33.96 \%$. Pada fungsi hutan lahan kering primer dari tahun 2002 hingga 2014 juga semakin menurun hingga 9.45\%, sedangkan semak belukar bertambah hingga $12.61 \%$. Pada fungsi sawah dan tanah terbuka juga berkurang. Bertambahnya besarnya wilayah pemukiman akan berdampak pada berkurangnya wilayah vegetasi, sehingga luas hutan, sawah maupun semak juga akan berkurang.

Tabel 3. Perubahan Penutupan Lahan

\begin{tabular}{|c|c|c|c|c|c|c|c|c|c|c|c|c|}
\hline \multirow{3}{*}{ Penutupan Lahan } & \multicolumn{2}{|c|}{2002} & \multicolumn{2}{|c|}{2006} & \multicolumn{2}{|c|}{2009} & \multicolumn{2}{|c|}{2014} & \multicolumn{4}{|c|}{ PERUBAHAN } \\
\hline & \multirow{2}{*}{$\mathrm{Km}^{2}$} & \multirow[t]{2}{*}{$\%$} & \multirow{2}{*}{$\mathrm{Km}^{2}$} & \multirow[t]{2}{*}{0} & \multirow{2}{*}{$\mathrm{Km}^{2}$} & & \multirow{2}{*}{$\mathrm{Km}^{2}$} & \multirow{2}{*}{$\%$} & \multirow{2}{*}{\begin{tabular}{|c|}
$2002-2006$ \\
$\%$
\end{tabular}} & \multirow{2}{*}{$\frac{2006-2009}{\%}$} & \multicolumn{2}{|c|}{\begin{tabular}{|l|l|}
$2009-2014$ & $2002-2014$ \\
\end{tabular}} \\
\hline & & & & & & & & & & & $\%$ & $\%$ \\
\hline Hutan Lahan K & 9.37 & 13.23 & 6.48 & 9.14 & 5.79 & 8.17 & 2.68 & 3.78 & -4.09 & -0.97 & -4.39 & -9.45 \\
\hline Hutan Tanaman Industri & 27.80 & 39.24 & 14.12 & 19.93 & 5.68 & 8.02 & 3.74 & 5.28 & -19.30 & -11.91 & -2.74 & -33.96 \\
\hline Pemukiman & 5.71 & 8.06 & 10.74 & 15.15 & 23.65 & 33.37 & 29.78 & 42.02 & 7.09 & 18.21 & 8.65 & 33.96 \\
\hline Sawah & 17.95 & 25.33 & 23.38 & 32.99 & 19.06 & 26.89 & 17.81 & 25.13 & 7.66 & -6.09 & -1.76 & -0.20 \\
\hline Semak/Belukar & 6.93 & 9.78 & 15.48 & 21.85 & 15.59 & 22.00 & 15.86 & 22.38 & 12.07 & 0.15 & 0.38 & 12.61 \\
\hline Tanah Terbuka & 3.09 & 4.36 & 0.66 & 0.94 & 1.10 & 1.55 & 0.99 & 1.40 & -3.43 & 0.61 & -0.15 & -2.96 \\
\hline & 70.86 & 100.00 & 70.86 & 100.00 & 70.86 & 100.00 & 70.86 & 100.00 & & & & \\
\hline
\end{tabular}




\section{c. Hasil Analisa ARCSWAT}

Pada penelitian ini menggunakan ketelitian sebesar $1.5 \mathrm{Km}^{2}$, sehingga terbentuk DAS dengan total $70.865 \mathrm{Km}^{2}$. Berdasarkan pada ketelitian yang digunakan maka pada proses ini akan terbentuk 23 subbasin.

Hasil pembentukan HRU berupa informasi mengenai unit analisis hidrologi yang memiliki karakteristik penutupan lahan dan jenis tanah yang spesifik, sehingga didapatkan suatu wilayah yang memiliki karakteristik hidrologi yang sama. Pembentukan HRU dengan metode tumpang tindih antara Peta Penutupan Lahan, Jenis Tanah dan Kemiringan Lahan dengan menggunakan Thresold by percentage, dimana masing-masing persentase threshold sebesar $1 \%$. HRU yang terbentuk pada masing-masing tahun berbeda, pada tahun 2002 sebanyak 432 HRU dalam 23 Subbasin, tahun 2006 sebanyak 410 HRU, tahun 2009 sebanyak 366 HRU dan tahun 2014 sebanyak 336 HRU.

d. Kalibrasi dan validasi Model

Pada proses kalibrasi dilakukan 11 kali iterasi dengan 500 kali simulasi di setiap iterasinya. Pada iterasi ke-11 didapatkan hasil p-faktor sebesar 0.85 , r-faktor sebesar $0.66, \mathrm{R}^{2}$ sebesar 0.96 dan NS sebesar 0.93. sedangkan pada proses validasi didapatkan p-faktor sebesar 0.83 , r-faktor sebesar $0.72, \mathrm{R}^{2}$ sebesar 0.89 dan NS sebesar 0.86. Berdasarkan hasil tersebut menunjukkan bahwa pada proses kalibrasi $85 \%$ debit observasi berada pada wilayah 95PPU, sehingga kalibrasi dinilai valid, nilai $\mathrm{R}^{2}$ yang mendekati nilai 1 , menunjukkan bahwa hasil simulasi mendekati nilai aktual di lapangan, dan nilai NS juga menunjukkan bahwa fluktuasi debit simulasi debit hampir sama dengan fluktuasi debit lapangan.

Tabel 4. Hasil Proses Kalibrasi Dan Validasi

\begin{tabular}{|l|r|r|}
\hline Variabel & Kalibrasi & \multicolumn{1}{c|}{ Validas i } \\
\hline p-factor & 0.85 & 0.83 \\
\hline r-factor & 0.66 & 0.72 \\
\hline $\mathrm{R}^{2}$ & 0.96 & 0.89 \\
\hline $\mathrm{NS}$ & 0.93 & 0.86 \\
\hline
\end{tabular}

Sumber: Hasil Analisa SWAT-CUP

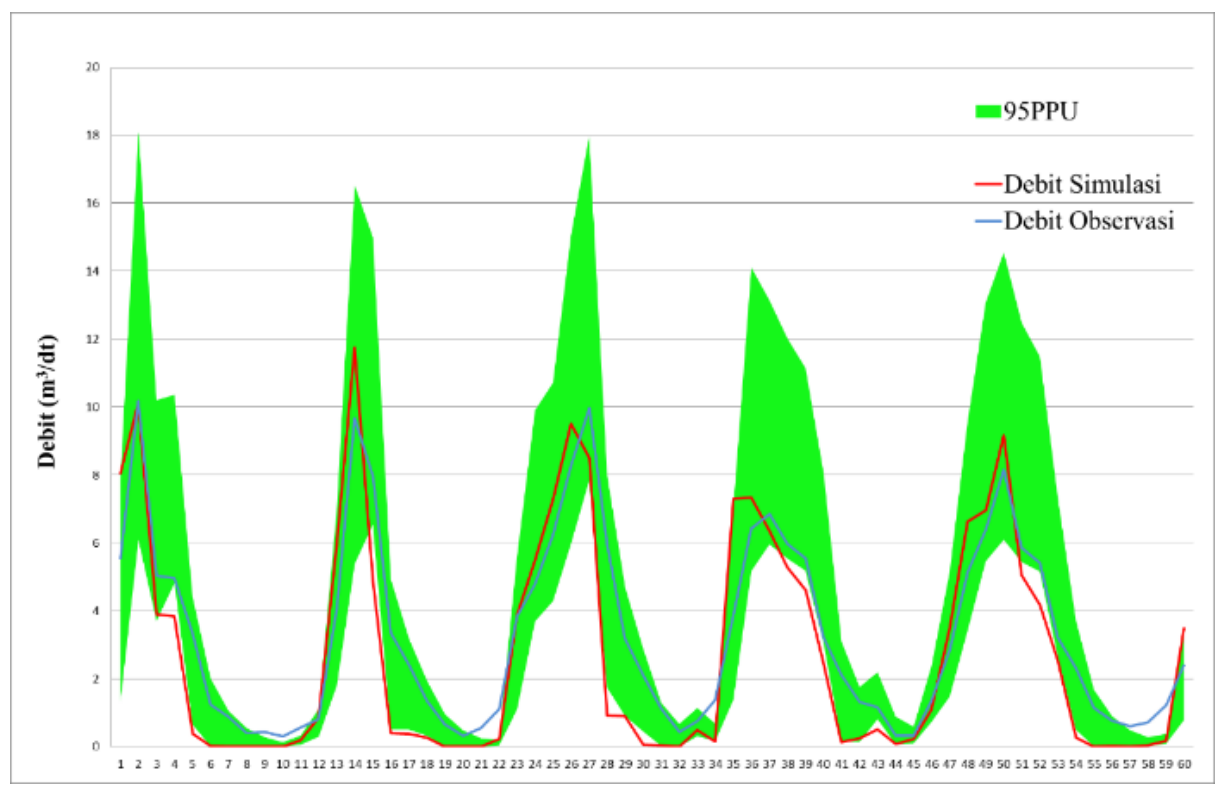

Gambar 3. Grafik Hasil Kalibrasi

e. Analisa Perubahan Curve Number Tabel 5. Luas Kelompok Hidrologi Tanah

\begin{tabular}{|c|c|c|}
\hline $\begin{array}{c}\text { Kelompok Hidrologi } \\
\text { Tanah }\end{array}$ & $\begin{array}{c}\text { Luas } \\
\left(\mathrm{Km}^{2}\right)\end{array}$ & $\begin{array}{c}\text { Persentase } \\
(\%)\end{array}$ \\
\hline A & 32.619 & 46.0 \\
\hline B & 9.067 & 12.8 \\
\hline C & 29.178 & 41.2 \\
\hline Total & 70.865 & 100.0 \\
\hline
\end{tabular}

Sumber: Hasil Analisa
Penentuan nilai curve number didasarkan pada kondisi hidrologi tanah dan AMC yang terdapat pada data properti tanah serta penutupan lahan.

Berdasarkan data properti tanah, pada wilayah penelitian berada dalam kelompok hidrologi tanah (KHT) A, B dan C dengan sebaran seperti yang terdapat dalam peta berikut. 
Terdapat tiga KHT dalam wilayah penelitian yaitu A, B dan C. Luas KHT A sebesar $32.62 \mathrm{Km}^{2}$, luas KHT B sebesar 9.07 $\mathrm{Km}^{2}$ dan luas KHT C sebesar $29.18 \mathrm{Km}^{2}$.

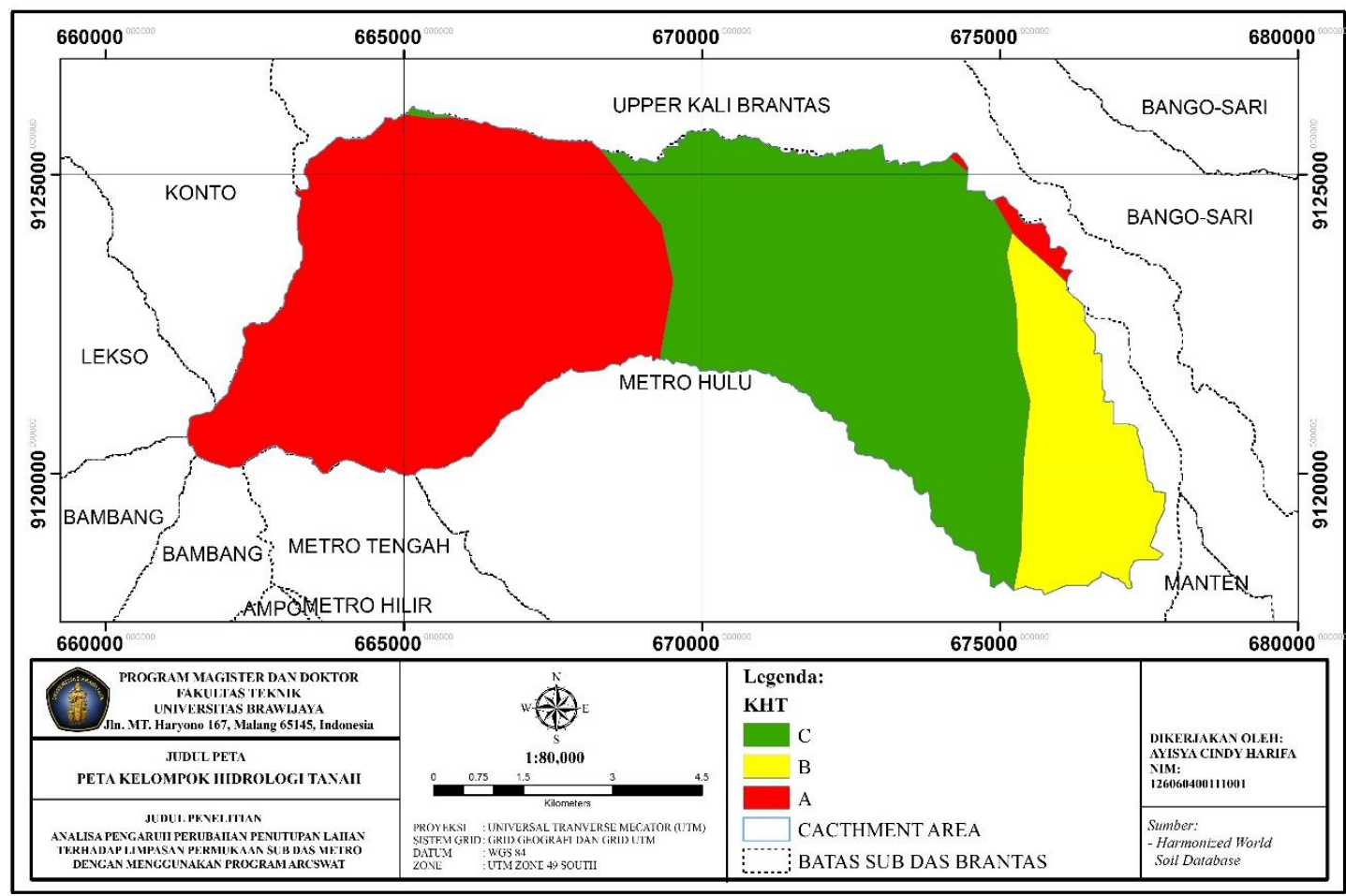

Gambar 3. Peta sebaran kelompok hidrologi tanah

Tabel 6. Perubahan Nilai CN Setiap Penutupan Lahan

\begin{tabular}{|c|c|c|c|c|}
\hline Penutupan Lahan & Tahun & $\mathbf{C N}$ & Tahun & $\mathbf{C N}$ \\
\hline Hutan Lahan Kering Primer & \multirow{6}{*}{2002} & 18.0 & \multirow{6}{*}{2006} & 30.0 \\
\hline Hutan Tanaman Industri & & 21.3 & & 56.8 \\
\hline Permukiman & & 41.0 & & 70.0 \\
\hline Sawah & & 33.0 & & 70.7 \\
\hline Semak Belukar & & 0.0 & & 56.5 \\
\hline Tanah Terbuka & & 27.0 & & 74.0 \\
\hline Penutupan Lahan & Tahun & $\mathbf{C N}$ & Tahun & $\mathbf{C N}$ \\
\hline Hutan Lahan Kering Primer & \multirow{6}{*}{2009} & 36.0 & \multirow{6}{*}{2014} & 45.0 \\
\hline Hutan Tanaman Industri & & 62.7 & & 57.0 \\
\hline Permukiman & & 82.3 & & 91.6 \\
\hline Sawah & & 71.0 & & 72.5 \\
\hline Semak Belukar & & 49.0 & & 68.0 \\
\hline Tanah Terbuka & & 76.0 & & 77.0 \\
\hline
\end{tabular}

Sumber: Hasil Analisa

Setiap penutupan lahan memiliki empat nilai $\mathrm{CN}$ yang akan dipilih sesuai dengan kelas KHT yang ada. Pemilihan nilai $\mathrm{CN}$ terdapat pada proses pembentukan HRU. Nilai $\mathrm{CN}$ dari tahun ke tahun akan semakin besar, berdasarkan hasil simulasi nilai $\mathrm{CN}$ maksimum adalah 96 terdapat pada penutupan lahan tahun 2014 dan $\mathrm{CN}$ minimum adalah 11 terdapat pada penutupan lahan tahun 2002. Nilai CN dari penutupan lahan 2006, 2009 dan
2014 lebih besar dari nilai $\mathrm{CN}$ hasil simulasi Rencana tata ruang wilayah pemerintah setempat.

Pada tahun 2002 nila CN sebesar 36.15 , kemudian pada tahun 2006 naik hingga $96.36 \%$ dari tahun 2002 sebesar 70.99. Pada tahun 2009 kenaikan CN hanya sebesar $8.92 \%$ dari tahun 2006 sebesar 77.32 dan pada tahun 2014 nilai CN naik kembali hingga 9.45\% dari tahun 2009 sebesar 84.63.

Jika dibandingkan dengan dengan $\mathrm{CN}$ dari rencana tata ruang wilayah setempat, maka nilai CN rerata dari tahun 2006, 2009 dan 2014 lebih besar. Tahun 2006 lebih besar 6.16\% dari CN RTRW, tahun 2009 lebih besar $15.63 \%$ dan tahun 2014 lebih besar $26.56 \%$. Adanya perubahan fungsi penutupan lahan dari area yang memiliki vegetasi yang rapat menjadi area dengan perlakuan manusia, sehingga kerapatan vegetasi berkurang, menjadi penyebab peningkatan pada nilai $\mathrm{CN}$.

\section{f. Analisa Pengaruh Perubahan Penutupan Lahan}

Dampak perubahan Penutupan lahan terhadap karakteristik hidrologi dalam hal ini adalah volume limpasan dan debit sungai yang dilakukan dengan model ARCSWAT dengan 
menggunakan parameter masukan berdasarkan penutupan lahan tahun 2002, 2006, 2009 dan 2014. Semua parameter masukan dianggap sama seperti karakteristik tanah, iklim dan beberapa parameter lain yang terdapat dalam program.

Perubahan fungsi penutupan lahan area dengan vegetasi yang rapat menuju area yang dikelola manusia, menyebabkan berkurangnya area resapan air di wilayah studi dan meningkatnya volume limpasan permukaan.

\section{g. Analisa Limpasan permukaan}

Limpasan permukaan merupakan bagian air hujan yang mengalir dalam bentuk lapisan tipis di atas permukaan tanah. Aliran permukaan akan mengalir menuju sungai dengan waktu yang cepat. Perubahan fungsi lahan sangat berpengaruh pada limpasan permukaan. Akan tetapi sangat sulit untuk mengukur besarnya limpasan permukaan. sehingga selama ini para peneliti hanya melakukan kalkulasi untuk memprediksi besarnya limpasan permukaan. Analisa yang dilakukan SWAT merupakan salah pendekatan yang dapat memperkirakan besarnya limpasan permukaan tersebut. Metode yang digunakan ada berbagai macam, dalam SWAT ada dua metode yang digunakan yaitu SCS curve number dan Green Amp Infiltration method. Penelitian ini memilih metode SCS curve number, karena menghasilkan debit yang lebih akurat.

Curah hujan yang jatuh di DAS diasumsikan sama tiap tahun dengan tujuan untuk melihat perubahan limpasan akibat pengaruh perubahan penutupan lahan tanpa melihat pengaruh perubahan curah hujan atau iklim. Hujan bulanan tertinggi terjadi pada bulan Februari sebesar 302.41, pada bulan yang sama limpasan yang terjadi pada tahun 2002 adalah sebesar $16.02 \%$ dari hujan bulanan tersebut. Limpasan yang terjadi pada tahun 2002 adalah sebesar $48.45 \mathrm{~mm}$.

Setelah terjadi penutupan lahan $\mathrm{CN}$ terbobot meningkat dari 36.15 menjadi 70.99 , peningkatan nilai $\mathrm{CN}$ menyebabkan peningkatan pada limpasan, pada tahun 2006 limpasan meningkat hingga $97.5 \mathrm{~mm}$ pada bulan Februari. Menurunnya luasan hutan tanaman industri dan meningkatnya lahan sawah menjadi penyebab peningkatan limpasan.

Pada tahun 2009 limpasan meningkat $39.37 \%$ dari curah hujan yang terjadi pada bulan tersebut. Bertambahnya limpasan juga diakibatkan oleh meningkatnya nilai $\mathrm{CN}$ terbobot yaitu sebesar 77.32, sehingga menyebabkan limpasan meningkat hingga $119.05 \mathrm{~mm}$. meningkatnya luasan pemukiman, sawah dan semak/belukar menjadi penyebab peningkatan limpasan pada tahun 2009 ini.

Pada tahun 2014 limpasan semakin meningkat hingga $45.80 \%$ dari curah hujan yang terjadi pada bulan tersebut. $\mathrm{CN}$ terbobot pada tahun 2014 adalah semakin meningkat sebesar 84.63. Perubahan fungsi lahan dari sawah dan lahan bervegetasi lainnya menjadi pemukiman menjadi penyebab meningkatnya limpasan permukaan pada tahun ini.

Berdasarkan hasil yang diperoleh, maka di wilayah hulu sungai Metro ini, perubahan fungsi lahan akibat campur tangan dan perlakuan manusia memberikan pengaruh yang cukup besar dalam peningkatan limpasan permukaan.

Tabel 7. Perbandingan Limpasan Permukaan dengan Hujan Bulanan

\begin{tabular}{|c|r|r|r|r|r|r|}
\hline Bulan & Rain & PL 2002 & PL 2006 & PL 2009 & PL 2014 & RTRW \\
\hline Jan & 273.28 & 29.3 & 75.46 & 96.71 & 112.36 & 64.53 \\
\hline Feb & 302.41 & 48.45 & 97.5 & 119.05 & 136.59 & 85.51 \\
\hline Mar & 247.21 & 32.34 & 74.41 & 93.66 & 107.47 & 63.46 \\
\hline Apr & 150.53 & 13.75 & 38.86 & 51.09 & 59.33 & 32.21 \\
\hline May & 71.94 & 3.78 & 13.6 & 19.33 & 22.46 & 10.37 \\
\hline Jun & 22.21 & 0.78 & 4.5 & 6.24 & 7.16 & 3.61 \\
\hline Jul & 10.82 & 0.3 & 1.27 & 2.24 & 2.69 & 0.82 \\
\hline Aug & 13.27 & 0.82 & 3.88 & 4.64 & 5.26 & 2.96 \\
\hline Sep & 28.38 & 2.17 & 6.79 & 8.54 & 9.87 & 5.42 \\
\hline Oct & 41.38 & 1.34 & 4.29 & 6.93 & 9.01 & 3.28 \\
\hline Nov & 186.94 & 15.38 & 45.52 & 59.11 & 70.07 & 38.44 \\
\hline Dec & 240.84 & 29.34 & 64.47 & 81.08 & 94.33 & 56.1 \\
\hline Rerata & $\mathbf{1 3 2 . 4 3}$ & $\mathbf{1 4 . 8 1}$ & $\mathbf{3 5 . 8 8}$ & $\mathbf{4 5 . 7 2}$ & $\mathbf{5 3 . 0 5}$ & $\mathbf{3 0 . 5 6}$ \\
\hline
\end{tabular}

Sumber: Hasil Analisa

\section{h. Perubahan Debit Sungai}

Selain limpasan permukaan, debit sungai juga dipengaruhi oleh perubahan penutupan lahan, berdasarkan simulasi didapatkan bahwa setiap tahun mengalami kenaikan. Debit tahunan maksimum yang dihasilkan adalah sebesar $3.591 \mathrm{~m}^{3} / \mathrm{dt}$ dari simulasi penutupan lahan tahun 2014 dan debit minimum adalah $1.923 \mathrm{~m}^{3} / \mathrm{dt}$ dari simulasi penutupan lahan tahun 2002.

Peningkatan debit rerata tahunan yang terjadi dari tahun 2002 hingga 2006 adalah sebesar $5.0 \%$ sebesar $0.115 \mathrm{~m}^{3} / \mathrm{dt}$. Pada tahun 2006 meningkat debit rerata tahunan sebesar $0.9 \%$ dari tahun 2006 sebesar $0.021 \mathrm{~m}^{3} / \mathrm{dt}$. Pada tahun 2014 meningkat 2\% dari tahun 2009 sebesar $0.049 \mathrm{~m}^{3} / \mathrm{dt}$.

Apabila dilihat dari debit rerata setiap penutupan lahan dibandingkan dengan debit 
yang dihasilkan dari simulasi RTRW maka pada penutupan lahan tahun 2006, 2009 dan 2014 memiliki debit rerata diatas debit hasil simulasi RTRW.

Tahun 2014 memiliki debit 5.3\% lebih besar dari debit hasil simulasi RTRW sebesar $0.125 \mathrm{~m} 3 / \mathrm{dt}$. Hal tersebut menguatkan bahwa penutupan lahan tahun 2006, 2009 dan 2014 tidak sesuai dengan RTRW pemerintah setempat.

Tabel 8. Debit Sungai Hasil Simulasi Tahunan $\left(\mathrm{m}^{3} / \mathrm{dt}\right)$

\begin{tabular}{|c|r|r|r|r|r|}
\hline Date & PL 2002 & PL 2006 & PL 2009 & PL 2014 & RTRW \\
\hline 2002 & 1.923 & 2.030 & 2.057 & 2.092 & 1.955 \\
\hline 2003 & 2.069 & 2.261 & 2.293 & 2.351 & 2.195 \\
\hline 2004 & 2.946 & 3.073 & 3.084 & 3.122 & 3.051 \\
\hline 2005 & 2.064 & 2.172 & 2.209 & 2.275 & 2.081 \\
\hline 2006 & 2.344 & 2.296 & 2.321 & 2.366 & 2.318 \\
\hline 2007 & 1.957 & 2.218 & 2.243 & 2.297 & 2.094 \\
\hline 2008 & 2.111 & 2.141 & 2.158 & 2.204 & 2.111 \\
\hline 2009 & 1.931 & 2.069 & 2.111 & 2.160 & 2.042 \\
\hline 2010 & 3.429 & 3.577 & 3.548 & 3.591 & 3.468 \\
\hline 2011 & 2.247 & 2.332 & 2.355 & 2.406 & 2.300 \\
\hline Rerata & $\mathbf{2 . 3 0 2}$ & $\mathbf{2 . 4 1 7}$ & $\mathbf{2 . 4 3 8}$ & $\mathbf{2 . 4 8 6}$ & $\mathbf{2 . 3 6 2}$ \\
\hline
\end{tabular}

Sumber: Hasil Analisa

\section{i. Penilaian Kinerja DAS}

Konsep dasar model hidrologi pada akhirnya akan menjadi data dasar penyusunan pengelolaan DAS. Indikator yang terdapat dalam penilaian DAS memberikan informasi terkait kondisi DAS pada saat evaluasi. Pada proses penilaian ini, beberapa indikator yang digunakan adalah yang menyangkut penutupan lahan, debit air dan erosi.

Penilaian kinerja DAS menunjukkan bahwa indeks penggunaan lahan memiliki nilai Jelek yang diakibatkan oleh luasan yang memiliki area vegetasi permanen kurang dari nilai standar yang dianjurkan sebesar $75 \%$.

Sedangkan hingga tahun 2014 area bervegetasi permanen di wilayah studi terus mengalami penurunan.

Kesesuaian penggunaan lahan memiliki nilai Jelek, yang diakibatkan oleh fungsi lahan dari tahun ke tahun yang tidak sesuai dengan yang ada dalam RTRW.

Nilai Indeks erosi Jelek, penyebabnya erosi aktual yang terjadi melebihi erosi yang diperbolehkan.

Pengelolaan lahan memiliki nilai Baik, dengan adanya campur tangan manusia maka pengelolaan lahan seperti pembuatan terasering atau perkuatan tebing akan menyebabkan aktivitas erosi yang dapat diminimalisir, hal tersebut juga dipengaruhi oleh kemiringan lahan.

Tabel 9. Hasil Penilaian Kinerja DAS

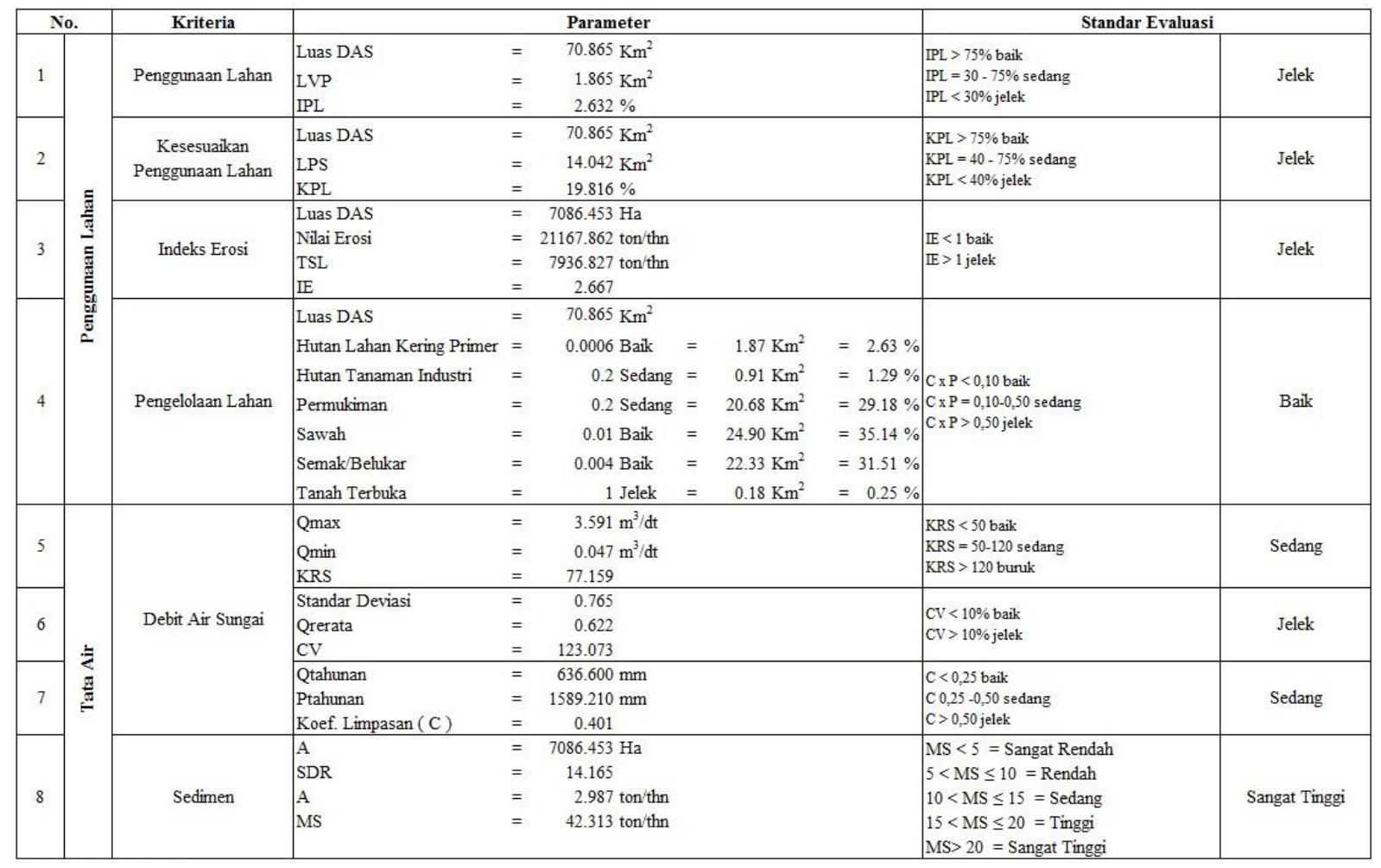


maksimum dan minimum. Pada saat terjadi hujan < $250 \mathrm{~mm}$ debit dasar mengalami penurunan, namun penurunan tidak terjadi secara terus menerus. Sedangkan pada saat hujan $>250 \mathrm{~mm}$, sering terjadi perubahan yang mencolok antara debit maksimum dan debit dasar. Hal ini menunjukkan DAS sudah mengalami masalah, dan harus segera ditangani.Berdasarkan hasil simulasi, keseragaman hasil dari debit bulanan dari tahun 2002 hingga 2011 memiliki nilai Jelek, banyak faktor yang menyebabkan ketidakseragaman, diantara hujan yang tidak merata di sepanjang tahun dan juga perubahan iklim dari tahun ke tahun. Penilaian terhadap koefisien limpasan memiliki nilai Sedang, nilai ini menunjukkan bahwa meskipun pada saat musim kering tetap terjadi limpasan, atau tetap terdapat aliran di sungai, walaupun dengan debit yang rendah. Penilaian terhadap nisbah hantar sedimen memiliki nilai Baik. Penilaian sedimen dinilai dari muatan sedimen. Dalam penilaian muatan sedimen nilai yang diberikan adalah sangat tinggi, hal ini karena muatan sedimen cukup besar lebih dari 20 ton/ha/th.

Berdasarkan penilaian tersebut, maka pada catchment area Metro dapat dikatakan belum memiliki kinerja yang buruk, karena masih banyak potensi penurunan kinerja yang akan terjadi. Pada catchment area Metro diperlukan adanya penangan tambahan untuk menanggulangi penurunan kinerja DAS seperti arahan pengelolaan penggunaan lahan yang lebih jelas dengan penambahan area yang bervegetasi, dengan begitu maka kualitas kinerja DAS akan semakin baik, yang akan berdampak pada kualitas manusia yang berada di lingkungan tersebut.

Adanya sangsi tegas dalam pelanggaran rencana tata ruang wilayah juga diperlukan. Apabila regulasi sudah tidak dapat diandalkan maka penanganan secara teknik harus diperlukan seperti pembuatan waduk sebagai tampungan, pembuatan biopori untuk bantuan resapan air, dan juga perbaikan dranasi di wilayah-wilayah yang kedap air.

\section{KESIMPULAN DAN SARAN}

\section{a. Kesimpulan}

Berdasarkan hasil analisa pada bab-bab sebelumnya maka kesimpulan dalam penelitian adalah sebagai berikut:

1. Berdasarkan hasil klasifikasi penutupan lahan kondisi vegetasi pada tahun 2014, terdiri dari hutan lahan kering primer sebesar 3.78\% dari keseluruhan area studi, hutan tanaman industri $5.28 \%$, pemukiman $42.02 \%$, sawah $25.13 \%$, semak belukar $22.38 \%$ dan tanah terbuka sebesar $1.4 \%$. berdasarkan hasil klasifikasi tersebut, keseluruhan wilayah yang memiliki vegetasi permanen kurang dari $75 \%$.

2. Hasil simulasi menunjukkan bahwa vegetasi pada tahun 2014 hanya 57.92\% dari luas keseluruhan wilayah studi. Adanya pertambahan penduduk dan perlakuan manusia maka luasan vegetasi yang terdapat pada wilayah ini berkurang cukup signifikan pada tahun 2002 luas vegetasi sebesar $66.6 \%$, pada tahun 2006 berkurang menjadi $51.9 \%$, pada tahun 2009 berkurang hingga 39.7 dan pada tahun 2014 menjadi $32.8 \%$. Jika diakumulasi perubahan luas vegetasi tahun 2014 berkurang sebesar 50.7\% dari tahun 2002 . Berdasarkan analisa hasil simulasi menunjukkan pola perubahan lahan dari tahun 2002 hingga 2014 adanya perluasan pada area pemukiman dan penyempitan pada area vegetasi.

3. Penurunan luas vegetasi menyebabkan nilai $\mathrm{CN}$ yang semakin bertambah besar di setiap tahunnya. Hasil analisa ARCSWAT menunjukkan bahwa terjadi peningkatan nilai $\mathrm{CN}$ sebesar $134.1 \%$ dari tahun 2002 hingga 2014, sedangkan jika dibandingkan dengan nilai CN dari RTRW tahun 2014 memiliki nilai $15.63 \%$ lebih besar. Limpasan permukaan yang terjadi pada tahun 2014 naik hingga tiga kali lipat dari tahun 2002 yaitu dari $291.09 \mathrm{~mm}$ hingga $866.67 \mathrm{~mm}$. Apabila penutupan lahan tahun 2014 dibandingkan dengan limpasan dari simulasi RTRW maka tahun 2014 memiliki nilai $43.14 \%$ lebih besar. Begitu juga dengan debit rearata tahunan dari setiap penutupan lahan, dari tahun 2002 hingga 2014 naik sebesar $8 \%$ sebesar $0.184 \mathrm{~m}^{3} / \mathrm{dt}$, jika dibandingkan dengan debit rerata hasil simulasi RTRW maka penutupan lahan tahun 2014 memiliki debit 5.3\% lebih besar yaitu sebesar $0.125 \mathrm{~m}^{3} / \mathrm{dt}$. Perubahan fungsi lahan akibat campur tangan dan perlakuan manusia memberikan pengaruh yang cukup besar dalam peningkatan nilai $\mathrm{CN}$, Limpasan permukaan dan debit sungai.

4. Berdasarkan penilaian kinerja DAS yang sesuai dengan Permenhut Nomor 52/KptsII/2001, maka hasil penilaian menunjukkan 
kinerja DAS dalam kriteria yang buruk dengan beberapa nilai buruk di beberapa indikator, seperti penggunaan lahan, kesesuaian penggunaan lahan, indeks erosi, variansi debit dan sedimen. Identifikasi dari beberapa faktor, maka faktor yang paling berpengaruh adalah perubahan fungsi lahan, dari area dengan vegetasi yang rapat menjadi area dengan campur tangan perlakuan manusia. Apabila vegetasi berkurang maka tata kelola lahan dan tata air, menyebabkan peningkatan erosi dan debit banjir, sehingga semakin tahun akan terjadi penurunan kinerja DAS.

b. Saran

1. Hasil penelitian ini diharapkan dapat menjadi dasar dalam pengambilan keputusan untuk pengelolaan wilayah catcment area Metro selanjutnya, agar dapat meningkatkan kualitas kinerja DAS.

2. Pada catchment area Metro diperlukan adanya penangan tambahan untuk menanggulangi penurunan kinerja DAS seperti arahan pengelolaan penggunaan lahan yang lebih jelas dengan penambahan area yang bervegetasi, dengan begitu maka kualitas kinerja DAS akan semakin baik, yang akan berdampak pada kualitas manusia yang berada di lingkungan tersebut.

3. Adanya sangsi tegas dalam pelanggaran rencana tata ruang wilayah juga diperlukan. Apabila regulasi sudah tidak dapat diandalkan maka penanganan secara teknik harus diperlukan seperti pembuatan waduk sebagai tampungan, pembuatan biopori untuk bantuan resapan air, dan juga perbaikan dranasi di wilayah-wilayah yang kedap air.

4. Untuk pengembangan penelitian selanjutnya diharapkan adanya perhitungan akurasi data, baik sebagai input model maupun sebagai pembanding.

\section{DAFTAR PUSTAKA}

Neitsch, Arnold, Kiniry, Srinivasan, \& William. (2004). Soil and Water Assessment Tools Input/Output File Documentation Version 2005. Texas: Agricultural Reasearch Service US.

PPSL, Unmul. 1997. Panduan Pelatihan Untuk Pelatih Pengelolaan Terpadu DAS Jilid 1. Pengembangan Pusat Studi Lingkungan, Direktorat Jenderal Pendidikan Tinggi Departemen Pendidikan dan Kebudayaan.

Rau, M. I. (2012). Analisa Debit Sungai Dengan Menggunakan Model SWAT Pada DAS Cipasauran, Banten. Tidak dipublikasi. Bogor: Institut Pertanian Bogor.

Riswanto, Eris. (2009). Evaluasi Akurasi Klasifikasi Penutupan Lahan Menggunakan Citra Alos Palsar Resolusi Rendah Studi Kasus Di Pulau Kalimantan. Tidak dipublikasi. Bogor: Institut Pertanian Bogor.

Sari, S. (2011). Studi Limpasan Permukaan Spasial Akibat Perubahan Penggunaan Lahan (Menggunakan Model Kineros). Jurnal Pengairan, 148-158.

Sosrodarsono, S., \& Takeda, K. (1997). Hidrologi Untuk Pengairan. Jakarta: PT. Pradnya Paramita. 